\title{
CHEMICAL SENSOR AND FIELD SCREENING TECHNOLOGY DEVELOPMENT: FUELS IN SOILS FIELD SCREENING METHOD VALIDATION
}

Topical Report

Reporting Period March 1996 - March 1997

By

Susan S. Sorini

John F. Schabron

April 1997

Work Performed Under Cooperative Agreement

DE-FC21-93MC30127 Task 8

For

In-Situ Inc.

Laramie, Wyoming

and

U.S. Department of Energy

Office of Fossil Energy

Federal Energy Technology Center

Morgantown, West Virginia

By

Western Research Institute

Laramie, Wyoming 


\section{DISCLAIMER}

Portions of this document may be illegible in electronic image products. Images are produced from the best available original document. 


\section{ACKNOWLEDGMENTS}

Field data for soil samples from the railroad site were provided by Dr. Seth Frisbie, Johnson Company, Montpelier, Vermont, and Dr. Eric Butler, Gradient Corporation, Cambridge, Massachusetts (both formerly with ENSR Consulting and Engineering, Acton, Massachusetts). Dr. Frisbie also provided the equations showing linear correlations between the two methods tested.

This report was prepared with the support of the U.S. Department of Energy (DOE), Federal Energy Technology Center, under Cooperative Agreement Number DE-FC21-93MC30127 and by In-Situ, Inc., Laramie, Wyoming. However, any opinions, findings, conclusions, or recommendations expressed herein are those of the author and do not necessarily reflect the views of the DOE.

This report was prepared as an account of work sponsored by an agency of the United States Government. Neither the United States Government nor any agencies thereof, nor any of its employees, makes any warranty, expressed or implied, or assumes any legal liability or responsibility for the accuracy, completeness, or usefulness of any information, apparatus, product, or process disclosed, or represents that its use would not infringe on privately owned rights. Reference herein to any specific commercial product, process, or service by trade name, trademark, manufacturer, or otherwise does not necessarily constitute or imply its endorsement, recommendation, or favoring by the United States Government or any agency thereof. The views and opinions of authors expressed herein do not necessarily state or reflect those of the United States Government or any agency thereof. 


\section{TABLE OF CONTENTS}

\section{Page}

LIST OF TABLES $\ldots \ldots \ldots \ldots \ldots \ldots \ldots \ldots \ldots \ldots \ldots \ldots \ldots \ldots \ldots \ldots$ iv

EXECUTIVE SUMMARY $\ldots \ldots \ldots \ldots \ldots \ldots \ldots \ldots \ldots \ldots \ldots \ldots$

OBJECTIVES $\ldots \ldots \ldots \ldots \ldots \ldots \ldots \ldots \ldots \ldots \ldots \ldots \ldots \ldots \ldots \ldots \ldots$

INTRODUCTION $\ldots \ldots \ldots \ldots \ldots \ldots \ldots \ldots \ldots \ldots \ldots \ldots \ldots \ldots \ldots \ldots \ldots$

DESCRIPTION OF THE WORK $\ldots \ldots \ldots \ldots \ldots \ldots \ldots \ldots \ldots \ldots \ldots \ldots \ldots \ldots \ldots$

Method Development and Collaborative Study Design . . . . . . . . . . . . 2

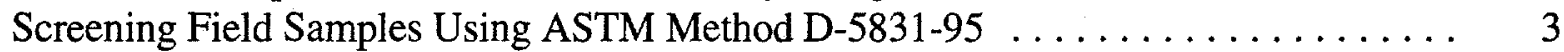

RESULTS AND DISCUSSION $\ldots \ldots \ldots \ldots \ldots \ldots \ldots \ldots \ldots \ldots \ldots \ldots$

Comparison of Diesel Fuel Concentrations Determined Using ASTM Method

D-5831-95 and Modified EPA Method $8015 \ldots \ldots \ldots \ldots \ldots \ldots \ldots$

Performance of Portable Field Versus Laboratory Equipment . . . . . . . . . . 5

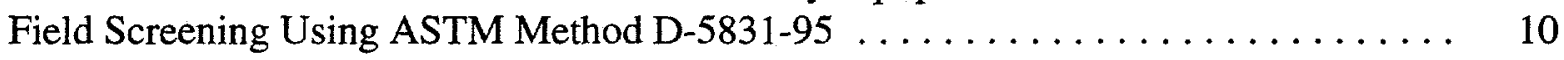

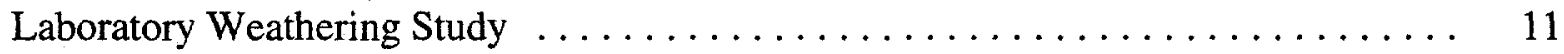

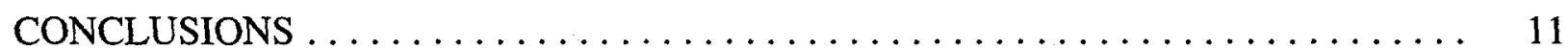

ASTM Method D-5831-95 Versus Modified EPA Method $8015 \ldots \ldots \ldots \ldots$. . . . 12

Performance of Portable Field Equipment Versus Laboratory Equipment

With ASTM Method D-5831-95 . . . . . . . . . . . . . . . . . . . . . 12

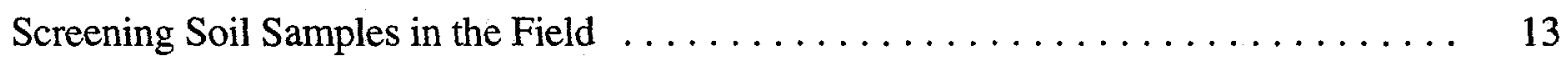

REFERENCES $\ldots \ldots \ldots \ldots \ldots \ldots \ldots \ldots \ldots \ldots \ldots \ldots \ldots \ldots \ldots \ldots$

TABLES $\ldots \ldots \ldots \ldots \ldots \ldots \ldots \ldots \ldots \ldots \ldots \ldots \ldots \ldots \ldots \ldots \ldots \ldots \ldots$ 


\section{LIST OF TABLES}

Table

Page

1. Collaborative Study Data Versus GC-FID Data, $\mathrm{mg} / \mathrm{Kg} \ldots \ldots \ldots \ldots \ldots \ldots$

2. Blank-Corrected Approximate Concentrations of Diesel Fuel in the

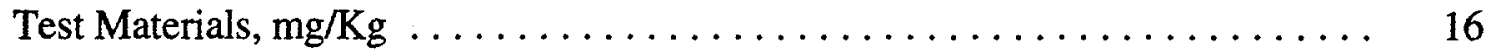

3. Blank-Corrected Estimated Concentrations of Diesel Fuel in the

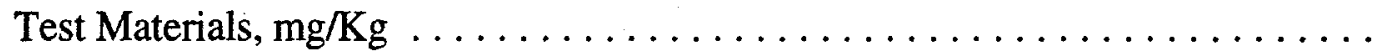

4. Final Statistics for the Approximate Concentration of Diesel Fuel in the Sand and

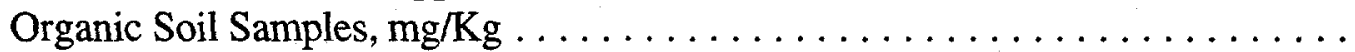

5. Final Statistics for the Estimated Concentration of Diesel Fuel in the Sand and

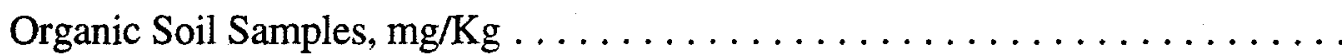

6. Portable Field Equipment and Laboratory Equipment Mean Concentration Values

7. Reproducibility Using Laboratory Equipment $\ldots \ldots \ldots \ldots \ldots \ldots \ldots \ldots . \ldots \ldots$

8. Reproducibility Using the Field Soil Test Kit $\ldots \ldots \ldots \ldots \ldots \ldots \ldots \ldots .22$

9. Repeatability Using Laboratory Equipment $\ldots \ldots \ldots \ldots \ldots \ldots \ldots \ldots \ldots$

10. Repeatability Using the Field Soil Test Kit $\ldots \ldots \ldots \ldots \ldots \ldots \ldots \ldots \ldots .24$

11. 95\% Reproducibility Limits for Testing Diesel-Spiked Sand and Organic Soil . . 25

12. 95\% Repeatability Limits for Testing Diesel-Spiked Sand and Organic Soil

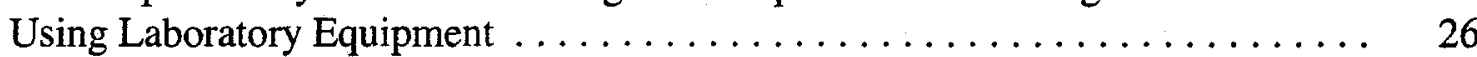

13. 95\% Repeatability Limits for Testing Diesel-Spiked Sand and Organic Soil

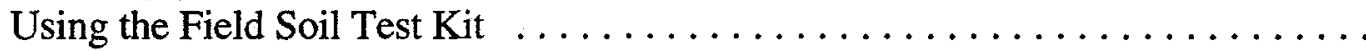

14. ASTM D-5831-95 and MADP Analysis Results for Five Diesel-Contaminated Soils from a Railroad Site, $\mathrm{mg} / \mathrm{kg}$ Dry Soil Basis $\ldots \ldots \ldots \ldots \ldots \ldots \ldots .28$

15. Percent Recovery from Soils Spiked to $422 \mathrm{mg} / \mathrm{kg}$ Diesel Fuel .......... 29 


\section{EXECUTIVE SUMMARY}

A new screening method for fuel contamination in soils was recently developed as American Society for Testing and Materials (ASTM) Method D-5831-95, Standard Test Method for Screening Fuels in Soils. This method uses low-toxicity chemicals and can be used to screen organic-rich soils. In addition, it is fast, easy, and inexpensive to perform. The screening method calls for extracting a sample of soil with isopropyl alcohol following treatment with calcium oxide. The resulting extract is filtered, and the ultraviolet absorbance of the extract is measured at $254 \mathrm{~nm}$. Depending on the available information concerning the contaminant fuel type and availability of the contaminant fuel for calibration, the method can be used to determine the approximate concentration of fuel contamination, an estimated value of fuel contamination, or an indication of the presence or absence of fuel contamination. Fuels containing aromatic compounds, such as diesel fuel and gasoline, as well as other aromatic-containing hydrocarbon materials, such as motor oil, crude oil, and coal oil, can be determined.

The screening method for fuels in soils was evaluated by conducting a collaborative study on the method and by using the method to screen soil samples at an actual field site. In the collaborative study, a sand and an organic soil spiked with various concentrations of diesel fuel were tested. Data from the collaborative study were used to determine the reproducibility (between participants) and repeatability (within participant) precision of the method for screening the test materials. The collaborative study data also provide information on the performance of portable field equipment versus laboratory equipment for performing the screening method and a comparison of diesel concentration values determined using the screening method versus a laboratory method. Data generated using the method to screen soil samples in the field provide information on the performance of the method in a typical "real-world" application. 


\section{OBJECTIVES}

The purpose of the current study was to evaluate a new screening method for fuels in soils. This was done by conducting a collaborative study on the method and by using the method to screen soil samples at an actual field site. Data from the collaborative study were used to determine the reproducibility (between participants) and repeatability (within participant) precision of the method for screening the test materials. The collaborative study data also provided information on the performance of portable field equipment versus laboratory equipment for performing the screening method and a comparison of diesel concentration values determined using the screening method versus a laboratory method. Another purpose of the study was to evaluate the use of the method in the field by reviewing data generated by one of the collaborative study participants at an actual field site.

\section{INTRODUCTION}

A field method for screening fuel contamination in soils was developed within American Society for Testing and Materials (ASTM) Main Committee D-34 on Waste Management (Sorini and Schabron 1996). This test method is ASTM Method D-5831-95, Standard Test Method for Screening Fuels in Soils (ASTM 1996). Unlike many of the existing methods for screening fuel contamination in soils, the ASTM method provides a fast, easy, and inexpensive procedure that uses low-toxicity chemicals and can be used to screen organic-rich soils.

The method calls for extracting a soil sample with isopropyl alcohol, filtering the extract, and measuring the ultraviolet (UV) absorbance of the extract at $254 \mathrm{~nm}$ (Schabron et al. 1995). Calcium oxide is added to the soil as a conditioning agent to minimize interferences from organic materials. If the contaminant fuel is available for calibration, the approximate concentration of the fuel in the soil can be calculated; if the fuel type is known, but a sample of the contaminant fuel is not available for calibration, an estimate of the contaminant fuel concentration can be calculated using an average response factor; and if the nature of the contaminant fuel is not known, the absorbance value is used to indicate the presence or absence of fuel contamination. Fuels containing aromatic compounds, such as diesel fuel and gasoline, as well as other aromatic-containing hydrocarbon materials, such as motor oil, crude oil, and coal oil can be determined using the method.

A collaborative study was conducted to determine the reproducibility (between participants) and repeatability (within participant) precision of the method when applied to two different soil types spiked with various levels of diesel fuel (Sorini and Schabron 1996). Data generated in the collaborative study also provide information on the performance of portable field equipment versus 
laboratory equipment for performing the screening method and a comparison of diesel concentration values determined using the screening method versus a laboratory method. The purpose of this paper is to further evaluate ASTM Method D-5831-95 using these data. In addition, the ASTM method was used to screen soil samples for fuel contamination at an actual field site. The field data generated using the method provide information on the performance of the method in a typical "real-world" application. The field data were provided by Eric Butler and Seth Frisbie, who at the time of the testing were with ENSR Consulting and Engineering, Acton, Massachusetts.

\section{DESCRIPTION OF THE WORK}

\section{Method Development and Collaborative Study Design}

Development of ASTM Method D-5831-95 and the collaborative study design have been described previously (Schabron et al. 1995, Sorini and Schabron 1996). Therefore, these are briefly summarized below.

The screening method became an ASTM standard test method in September 1995. The method that was approved by ASTM is the same method used by the eight participants in the collaborative study. Because the screening method can be performed in the laboratory using laboratory equipment or in the field using portable equipment, three of the participants used laboratory equipment; three participants used field equipment; and two used a combination of both for their testing. In the study, the six participants were randomly designated as Participant 1, 2, 3, etc.

Each participant tested seven materials in triplicate. The test materials were a sand spiked with three different concentrations of diesel fuel (test materials A, B, and C), an unspiked sand (test material D), an organic soil spiked with two different concentrations of diesel fuel (test materials $\mathrm{E}$ and F), and an unspiked organic soil (test material G). Each participant also determined the absorbance values of three calibration standard solutions, which they prepared to generate a calibration line. The participants used the absorbance values they recorded for the test materials to calculate both approximate and estimated diesel fuel concentrations in the materials.

The collaborative study materials were tested to make sure they met a specified homogeneity criterion prior to being sent to the participants. Homogeneity testing of the collaborative study test materials has also been described previously (Sorini and Schabron 1996) and is briefly summarized below. 
Homogeneity testing of the collaborative study materials involved mixing the bulk materials and analyzing subsamples of them for their diesel concentrations. Analysis was by gas chromatography with flame ionization detection (GC-FID) of methylene chloride extracts using modified EPA Method 8015 (EPA 1986). These data were used to establish a 95\% confidence interval for the concentration of diesel fuel in each test material (Guttman et al. 1971). The bulk materials were then taken through an additional mixing procedure. After additional mixing, two subsamples were withdrawn from each of the bulk materials and analyzed. The criterion for determining homogeneity was if the concentrations of diesel fuel determined in the two subsamples fell within the $95 \%$ confidence interval, expanded on both sides by $10 \%$, then the bulk material was homogeneous. The $95 \%$ confidence interval was expanded by $10 \%$ on both sides to allow for error in the GC-FID method due to extraction, concentration, calibration, GC sample injection, and diesel pattern interpretation. As stated, all of the test materials met this criterion before being sent to the participants for collaborative study testing.

\section{Screening Field Samples Using ASTM Method D-5831-95}

Five soil samples were obtained by ENSR Consulting and Engineering, Acton, Massachusetts, as part of a study of a confidential site that was continuously impacted by diesel fuel released during railroad maintenance activities for a period spanning approximately 80 years. These five samples were analyzed by the new ASTM Method D-5831-95 (ASTM 1996) and the Massachusetts Department of Environmental Protection (MADP) Draft Methods for Determining Extractable Petroleum Hydrocarbons (EPH) in soils. (MADEP 1995).

The MADEP method involves methylene chloride extraction of soil in a Soxhlet apparatus. The extract is dried with sodium sulfate, and the solvent is evaporated and solvent exchanged into hexane in a Kuderna-Danish concentrator. The extract is separated into aliphatic and aromatic fractions using a Sep Pak ${ }^{\mathrm{TM}}$ cartridge (Waters, Milford, MA) and eluting with hexane and methylene chloride, respectively. The extracts are analyzed using gas chromatography with flame ionization detection. The aliphatic fraction chromatogram is integrated within the $C_{9}$ through $C_{36}$ aliphatic hydrocarbon range, and the aromatic fraction chromatogram is integrated within the $C_{10}$ through $C_{22}$ aromatic hydrocarbon range. 


\section{RESULTS AND DISCUSSION}

\section{Comparison of Diesel Fuel Concentrations Determined Using ASTM Method D-5831-95 and Modified EPA Method 8015}

A total of 24 approximate and 24 estimated concentration values were generated for each test material by the eight participants in the collaborative study. In the statistical evaluation of these data, the mean approximate concentration of diesel fuel in each test material and the mean estimated concentration of diesel fuel in each test material were calculated (Sorini and Schabron 1996). These values can be compared with the concentration values determined in the test materials during homogeneity testing using the laboratory GC-FID method. This comparison is shown in Table 1.

In Table 1, higher absolute percent difference values between the screening method mean concentrations and the GC-FID mean values (20 to 47\%) are generally shown for the lower diesel concentrations at approximately 100 to $150 \mathrm{mg} / \mathrm{Kg}$. At diesel concentrations in the spiked sand and organic soil of approximately 400 to $970 \mathrm{mg} / \mathrm{Kg}$, the absolute percent differences between the screening method mean concentrations and the GC-FID mean values range from $0.5 \%$ to $25 \%$. Comparison of the screening method mean concentration values to the expanded $95 \%$ confidence intervals for the GC-FID analyses shows that seven of the ten mean concentration values determined using the screening method fall within the corresponding expanded $95 \%$ confidence interval or are just outside the interval by less than $20 \mathrm{mg} / \mathrm{Kg}$.

If the absolute values of the percent differences listed in Table 1 are averaged, the result is $20 \%$. This value can be used to give a general indication of how the results from the screening method and laboratory method may vary.

The concentrations determined using the screening method to test the diesel-spiked organic soil (materials $\mathrm{E}$ and $\mathrm{F}$ in table 1) are lower than the corresponding GC-FID values. This may be due to the spiked-organic soil adhering to the sides of the glass vials in which the material was shipped to the collaborative study participants. During addition of this material to the vials and during testing of the material using the screening method, the spiked organic soil adhered to the sides of the glass vials, and even with significant shaking, not all of the material could be loosened from the glass. It is believed that this may have resulted in lower concentrations of diesel fuel in the spiked organic soil that was removed from the glass vials by the participants for testing. Despite this problem and considering that the ASTM method is a screening method and the modified EPA method is a laboratory procedure, the variation between the values determined using the two methods would be acceptable in most cases. 


\section{Performance of Portable Field Equipment Versus Laboratory Equipment}

As mentioned, three of the collaborative study participants used portable field equipment to perform their testing, and three of the participants used laboratory equipment. The laboratory equipment included various models of a laboratory stir plate, balance, and spectrophotometer. The field equipment consisted of a soil test kit (patent pending) developed by the Western Research Institute and In-Situ, Inc. as part of the DOE jointly sponsored research program. The soil test kit contains a portable mechanical stirrer, portable balance, and portable photometer that measures ultraviolet absorbance at $254 \mathrm{~nm}$.

As mentioned, the participants in the collaborative study used the absorbance values they recorded to calculate the approximate and estimated concentrations of diesel fuel in the test materials. Calculations to correct those values for concentrations reported in the blank materials were performed by Western Research Institute using the data provided by the collaborative study participants. The blank-corrected approximate concentration data generated using laboratory equipment and field equipment are listed in Table 2 , and the blank-corrected estimated concentration data generated using laboratory equipment and field equipment are listed in Table 3.

ASTM Practice D-2777-86, Standard Practice for Determination of Precision and Bias of Applicable Methods of Committee D 19 on Water (ASTM 1991), and ASTM Practice E-691-87, Standard Practice for Conducting an Interlaboratory Study to Determine the Precision of a Test Method (ASTM 1990a),were used for guidance in evaluating the data listed in Tables 2 and 3. In this evaluation, the laboratory data and soil test kit data were treated as two separate data sets. The steps involved in the data evaluation were (1) eliminating "outlier" participants (participants who are so consistently high or low that their results are unreasonable), (2) eliminating individual outlier data points, (3) calculating reproducibility (between participants) standard deviation, (4) calculating repeatability (within participant) standard deviation, (5) determining the $95 \%$ reproducibility limit, and (6) determining the $95 \%$ repeatability limit.

The steps outlined in ASTM Practice D-2777-86 were applied to the data listed in Tables 2 and 3 to determine if any complete set of outlier participant data should be excluded from the statistical calculations. This evaluation showed no participant outliers in the blank-corrected approximate and estimated concentration data (Tables 2 and 3). After calculations to check for outlier participants were performed, the approximate and estimated mean concentrations of diesel fuel in the spiked test materials were calculated for the laboratory and soil test kit data. The data were then evaluated for individual outlier data points at the 5\% significance level as specified in ASTM Practice D-2777-86. Guidance given in ASTM Practice E-691-87 was also used to evaluate the data 
sets for individual outlier data points. If a data point was determined to be an outlier, it was removed from the data set, and the mean and standard deviation were recalculated using the remaining data.

The statistical values calculated after evaluating the data for outliers are the final statistics. Calculations outlined in ASTM Practices D-2777-86 and E-691-87 were used to determine the mean concentration, reproducibility (between participants) standard deviation, and repeatability (within participant) standard deviation for the approximate and estimated concentration data determined using both laboratory equipment and portable field equipment. These values are listed in Tables 4 and 5.

The mean concentrations of diesel fuel determined to be present in the test materials using laboratory equipment and field equipment (Tables 4 and 5) can be compared. This comparison is shown in Table 6. The maximum absolute percent difference between the mean concentration values determined using laboratory equipment and those determined using the soil test kit is $12 \%$, and for six of the comparisons shown in Table 6 , the absolute percent difference is $5 \%$ or less. This shows very good agreement between the results of the method when laboratory equipment is used and when portable field equipment is used. From the data shown in Table 6, it appears that at lower diesel concentrations in the spiked sand and organic soil, the results from using the method with laboratory equipment and field equipment may vary slightly more than at higher diesel concentrations.

The reproducibility and repeatability standard deviation values listed in Tables 4 and 5 were used to express the precision of the screening method when laboratory equipment is used and when portable field equipment is used. Information given in ASTM Practice E-177-90, Standard Practice for Use of the Terms Precision and Bias in ASTM Test Methods (ASTM 1990b), was used for guidance in expressing the precision of the screening method. The index used for expressing reproducibility and repeatability of the test method is the $95 \%$ limit on the difference between two test results. The $95 \%$ limit means that approximately $95 \%$ of all pairs of test results from users similar to the participants in the collaborative study can be expected to differ in absolute value by less than $2.8 \mathrm{~s}$ (standard deviation) or $2.8 \mathrm{CV} \%$ (percent coefficient of variation) (ASTM 1990b). This is expressed as:

$$
\begin{aligned}
& \mathrm{R}=95 \% \text { reproducibility limit }=2.8 \mathrm{~s}_{\mathrm{R}}=2.8 \mathrm{CV} \%_{\mathrm{R}} \\
& \mathrm{r}=95 \% \text { repeatability limit }=2.8 \mathrm{~s}_{\mathrm{r}}=2.8 \mathrm{CV} \%_{\mathrm{r}}
\end{aligned}
$$

The choice between use of $2.8 \mathrm{~s}$ or $2.8 \mathrm{CV} \%$ and the form of the precision statement depends on how the indexes vary with test level. 
- Listed in Table 7 are the $95 \%$ reproducibility limits expressed as $2.8 \mathrm{~S}_{\mathrm{R}}$ and $2.8 \mathrm{CV} \%_{\mathrm{R}}$ for the approximate and estimated concentration determinations using laboratory equipment to screen the diesel-spiked sand and organic soil.

- Listed in Table 8 are the $95 \%$ reproducibility limits for the approximate and estimated concentration determinations using portable field equipment to screen the diesel-spiked sand and organic soil; listed in Table 9 are the $95 \%$ repeatability limits expressed as $2.8 \mathrm{~s}_{\mathrm{r}}$ and $2.8 \mathrm{CV} \%_{\mathrm{r}}$ for the approximate and estimated concentration determinations using laboratory equipment to screen the diesel-spiked sand and organic soil.

- Listed in Table 10 are the $95 \%$ repeatability limits for the approximate and estimated concentration determinations using portable field equipment to screen the diesel-spiked sand and organic soil.

The data shown in Tables 7-10 were used to determine the $95 \%$ reproducibility and repeatability precision of the screening method using laboratory equipment and portable field equipment to test the diesel-spiked sand and organic soil.

The 95\% reproducibility limits for screening the diesel-spiked sand and diesel-spiked organic soil using laboratory equipment and the soil test kit are listed in Table 11. As shown in Table 11, the reproducibility (between participants) precision of the method using laboratory equipment to screen the diesel-spiked sand is proportional to the diesel concentration in the sand and is equal to $15 \%$ of the test result for both approximate and estimated concentration determinations. The reproducibility precision of the method using the soil test kit to screen the diesel-spiked sand varies with concentration, and is not as good as when laboratory equipment is used. At the lower approximate and estimated concentrations of 143 and $170 \mathrm{mg} / \mathrm{Kg}$, the $95 \%$ reproducibility limit is $47 \%$ and $58 \%$, respectively; and at the higher approximate and estimated concentrations (373 to $968 \mathrm{mg} / \mathrm{Kg}$ ), the $95 \%$ reproducibility precision ranges from $12 \%$ to $33 \%$ of the test result.

The reproducibility precision of the method using laboratory equipment to screen the dieselspiked organic soil varies with concentration and between approximate and estimated concentration determinations (Table 11). At the lower approximate and estimated concentrations of 108 and 127 $\mathrm{mg} / \mathrm{Kg}$, the $95 \%$ reproducibility limit is $65 \%$ and $46 \%$, respectively; and at the higher approximate and estimated concentrations of 646 and $759 \mathrm{mg} / \mathrm{Kg}$, the $95 \%$ reproducibility limit is $35 \%$ and $28 \%$, respectively. The reproducibility precision of the method using the soil test kit to screen the dieselspiked organic soil is proportional to the diesel concentration in the organic soil and varies between approximate and estimated diesel concentration determinations. For the approximate concentrations ranging from 95 to $579 \mathrm{mg} / \mathrm{Kg}$, the $95 \%$ reproducibility precision of the screening method using the soil test kit is $14 \%$ of the test result; and for estimated diesel concentrations in the organic soil 
ranging from 123 to $722 \mathrm{mg} / \mathrm{Kg}$, the reproducibility precision of the screening method using the soil test kit is $33 \%$ of the test result.

Review of the data listed in Table 11 shows that the 95\% reproducibility limits of the method for screening the diesel-spiked sand using the soil test kit are very similar to the $95 \%$ reproducibility limits of the method for screening the diesel-spiked organic soil using laboratory equipment. In addition, the $95 \%$ reproducibility limits of the method for screening the diesel-spiked sand using laboratory equipment and those determined for the method for screening the diesel-spiked organic soil using the soil test kit are somewhat similar.

For the diesel-spiked sand, the reproducibility precision of the method using laboratory equipment is better than when the soil test kit is used; and for the diesel-spiked organic soil, the overall reproducibility precision of the method using the soil test kit is better than when laboratory equipment is used. However, for the case in which laboratory equipment and the soil test kit give better reproducibility precision and for the case in which laboratory equipment and the soil test kit give lower reproducibility precision, the $95 \%$ reproducibility limits of the method are similar. As a result, in terms of reproducibility precision of the method, neither type of equipment can be judged more suitable for performing ASTM Method D-5831-95.

The 95\% repeatability limits for screening the diesel-spiked sand and organic soil using laboratory equipment are listed in Table 12. As shown in this table, the repeatability (within participant) precision of the method using laboratory equipment to screen the diesel-spiked sand is $13 \%$ across the diesel concentration range of 162 to $962 \mathrm{mg} / \mathrm{Kg}$. This is for both approximate and estimated concentration determinations. The repeatability precision of the method for screening the diesel-spiked organic soil using laboratory equipment is as follows: $21 \%$ for determining approximate concentrations across the diesel concentration range of 108 to $646 \mathrm{mg} / \mathrm{Kg} ; 22 \%$ at an estimated concentration of $127 \mathrm{mg} / \mathrm{Kg}$; and $9 \%$ at an estimated concentration of $759 \mathrm{mg} / \mathrm{Kg}$.

As shown in Table 12, the greatest variation between the $95 \%$ repeatability limits for screening the diesel-spiked sand and organic soil using laboratory equipment is only $13 \%$. This is across a concentration range of 108 to $962 \mathrm{mg} / \mathrm{Kg}$ for both approximate and estimated concentration determinations. Because of this small difference, the $95 \%$ repeatability limits for screening the dieselspiked sand and organic soil using laboratory equipment (Table 9) can be averaged to give an overall $95 \%$ repeatability limit. As shown in Table 12 , this value is $15 \%$ of the test result across a concentration range of 108 to $962 \mathrm{mg} / \mathrm{Kg}$.

The 95\% repeatability limits for screening the diesel-spiked sand and organic soil using the soil test kit are listed in Table 13. As shown in Table 13, the 95\% repeatability limits for screening 
the diesel-spiked sand using the soil test kit range from 11 to $26 \%$ for diesel concentrations of 143 to $968 \mathrm{mg} / \mathrm{Kg}$. The $95 \%$ repeatability limits for screening the organic soil using the soil test kit are similar, ranging from 13 to $23 \%$ across a concentration range of 95 to $722 \mathrm{mg} / \mathrm{Kg}$. These data show that across a concentration range of 95 to $968 \mathrm{mg} / \mathrm{Kg}$, the greatest variation between the $95 \%$ repeatability limits for screening the diesel-spiked sand and organic soil using the soil test kit is only $15 \%$. Because of this small difference, the $95 \%$ repeatability limits for screening the diesel-spiked sand and organic soil using the soil test kit (Table 10) can be averaged to give an overall 95\% repeatability limit. As shown in Table 13, this value is $18 \%$ of the test result across a concentration range of 95 to $968 \mathrm{mg} / \mathrm{Kg}$.

The 95\% reproducibility and repeatability limits listed in Tables 11-13 are specific to the test materials used in the collaborative study. For other soil types and fuel contaminants, these data may not apply. However, using these data to evaluate the precision of ASTM Method D-5831-95 using laboratory equipment versus portable field equipment shows the following.

- There is variation in the reproducibility precision of the method using laboratory equipment and the soil test kit to screen the diesel-spiked sand and organic soil. For screening the diesel-spiked sand, the reproducibility precision of the method using laboratory equipment is better than when the soil test kit is used. However, for screening the diesel-spiked organic soil, the overall reproducibility precision of the method using the soil test kit is better than when laboratory equipment is used.

- The reproducibility precision of ASTM Method D-5831-95 using laboratory equipment to screen the diesel-spiked sand is very good. The $95 \%$ reproducibility limit equals $15 \%$ of the test result for both approximate and estimated concentration determinations.

- For approximate diesel concentrations in the organic soil ranging from 95 to $579 \mathrm{mg} / \mathrm{Kg}$, the $95 \%$ reproducibility limit of the screening method using the soil test kit is $14 \%$ of the test result; and for estimated diesel concentrations in the organic soil ranging from 123 to $722 \mathrm{mg} / \mathrm{Kg}$, the $95 \%$ reproducibility limit is $33 \%$ of the test result.

- The 95\% reproducibility precision of the method for screening the diesel-spiked sand using the soil test kit and for screening the diesel-spiked organic soil using laboratory equipment varies with concentration for both approximate and estimated concentration determinations. In both cases, at lower concentrations, approximately 100 to $150 \mathrm{mg} / \mathrm{Kg}$, the reproducibility precision of the method is poor at approximately $55 \%$ and at higher concentrations, the reproducibility precision of the method is a little better at approximately $33 \%$. 
- For the case in which laboratory equipment and the soil test kit give better reproducibility precision and for the case in which laboratory equipment and the soil test kit give lower reproducibility precision, the $95 \%$ reproducibility limits of the method are similar. As a result, neither type of equipment can be judged more suitable for performing the method in terms of reproducibility precision.

- There is very good agreement between the repeatability precision of the screening method for testing the diesel-spiked sand and organic soil using laboratory equipment (15\% of the test result) and the repeatability precision of the screening method for testing the two materials using the soil test kit (18\% of the test result). In terms of repeatability precision, these data show comparable performance of the method using both types of equipment.

\section{Field Screening Using ASTM Method D-5831-95}

The petroleum product concentrations of five soil samples from a railroad site analyzed both by ASTM D-5831 and the MADEP EPH method are listed in Table 14. In all cases, the UV absorption results from ASTM D-5831 are higher than the sum of aliphatic and aromatic hydrocarbons (EPH) determined by gas chromatography using the MADEP method. This result is not surprising for several reasons. First, the contamination at the site occurred over a period of 80 years, and extensive weathering and bacterial degradation has occurred. The aliphatic portions will have been degraded by bacterial action, leaving the most persistent portion of the contaminants, the aromatic structures, which are tightly adsorbed to the soil matrix. These can have aromatic structures $>\mathrm{C}_{22}$, which would not be detected by the gas chromatography method. Also, isopropyl alcohol is a more powerful solvent for displacing adsorbed species than methylene chloride, resulting in a greater extraction efficiency. A similar trend was observed in a recent study in which spiked soils were weathered artificially (Schabron et al. 1995).

Drs. Seth Frisbie and Eric Butler provided data on least squares regression analysis of the data from Table 14. The equations are listed below.

$$
\begin{array}{ll}
\text { Aliphatics }(\mathrm{MADEP})=0.57 \times \mathrm{ASTM} & \mathrm{r}=0.96 \\
\text { Aromatics }(\mathrm{MADEP})=0.16 \times \text { ASTM } & \mathrm{r}=0.98 \\
\text { Total EPH }(\mathrm{MADEP})=0.73 \times \text { ASTM } & \mathrm{r}=0.96
\end{array}
$$

The data suggest that ASTM Method D-5831-95 is a statistically significant estimator of $\mathrm{C}_{9}$ through $\mathrm{C}_{36}$ aliphatic hydrocarbons, $\mathrm{C}_{10}$ through $\mathrm{C}_{22}$ aromatic hydrocarbons, and total extractable 
petroleum hydrocarbons. The slope of equation 3 also suggests that the total extractable petroleum hydrocarbons underestimates the true contaminant concentrations for these samples by about $27 \%$

\section{Laboratory Weathering Study}

As noted above, certain chemical changes occur due to oxidation, interaction with the matrix, and bacterial degradation when diesel-contaminated soil has weathered. The aromatic structures are more persistent while the aliphatic concentration decreases. The UV method specified with ASTM D-5831 can be quite useful, therefore, in assaying this residual aromatic material and relating this to the original diesel contamination level. This effect is dramatically illustrated by the results of UV, infrared (IR), and GC measurements on extracts of weathered diesel-spiked soils listed in Table 15 (Schabron et al. 1995). Each extraction by isopropyl alcohol (IPA) or Freon was performed on a separate spiked sample, so the results include the variability in the soil portions used for spiking and in the spiking itself. The UV, IR, and GC analyses were performed on the same Freon extract for each of the soil samples.

In general, the highest recoveries for the weathered materials are from the IPA extracts measured by UV at $254 \mathrm{~nm}$. The UV measurement results for Freon extracts are somewhat comparable for unaged spiked soils, but the recovery drops drastically following the severe conditions of the accelerated weathering. There was less material measured by UV in the Freon extracts from soils weathered at $60^{\circ} \mathrm{C}$ than at $40^{\circ} \mathrm{C}$. For silt, clay, or potting soils weathered at $60^{\circ} \mathrm{C}$, there was no UV-absorbing material observed in the Freon extracts. The IR and GC measurements of the Freon extracts show some material in all but one case, with significantly lower recoveries for the weathered materials. With aging, the Freon extracts generally show lower recoveries than the IPA extracts for the various measurement methods used. This probably is due to the more polar nature of IPA, which is a stronger solvent for displacing the relatively polar aromatic structures adsorbed on the surfaces of the soil particles. IPA is more effective for extracting the remaining aromatic material than Freon. The IPA/UV method seems to be particularly suitable for analyzing weathered contaminated soils for the more persistent aromatic components.

\section{CONCLUSIONS}

The following conclusions can be made concerning the performance of ASTM Method D5831-95 for screening the diesel-spiked sand and diesel-spiked organic soil used in the collaborative study and for screening soil samples in the field. 


\section{ASTM Method D-5831-95 Versus Modified EPA Method 8015}

- The average absolute percent difference between the approximate and estimated diesel concentrations determined using ASTM Method D-5831-95 and the diesel concentrations determined using modified EPA Method 8015 to test the diesel-spiked sand and organic soil is $20 \%$. This value can be used to give a general indication of how results from using the screening method and laboratory method may vary. This variation would be acceptable in most cases.

\section{Performance of Portable Field Equipment Versus Laboratory Equipment With ASTM Method D-5831-95}

- Average diesel concentrations determined using laboratory equipment and the soil test kit to screen the diesel-spiked sand and diesel-spiked organic soil using ASTM Method D-5831-95 are comparable. In all cases, they vary by $12 \%$ or less. In terms of test results, this shows comparable performance of the method using both types of equipment.

- There is variation in the reproducibility (between participants) precision of ASTM Method D-5831-95 using laboratory equipment and the soil test kit to screen the diesel-spiked sand and organic soil. For screening the diesel-spiked sand, the reproducibility precision of the method using laboratory equipment is better than when the soil test kit is used; and for screening the diesel-spiked organic soil, the overall reproducibility precision of the method using the soil test kit is better than when laboratory equipment is used. However, for the case in which laboratory equipment and the soil test kit give better reproducibility precision and for the case in which laboratory equipment and the soil test kit give lower reproducibility precision, the $95 \%$ reproducibility limits of the method are similar. As a result, in terms of reproducibility precision of the method, neither type of equipment can be judged more suitable for performing ASTM Method D-5831-95.

There is good agreement between the repeatability (within participant) precision of ASTM Method D-5831-95 for testing the diesel-spiked sand and organic soil using laboratory equipment (15\% of the test result) and the repeatability precision of the screening method for testing the two materials using the soil test kit (18\% of the test result). In terms of repeatability precision, these data show comparable performance of the method using both types of equipment. 


\section{Screening Soil Samples in the Field}

The measured concentration of petroleum hydrocarbon material in highly weathered soil samples was higher with the isopropyl alcohol extraction/UV absorption method than with the methylene chloride/gas chromatography method or Freon extraction method. This can be due to differences in extraction efficiency for the solvents and differences in the measurement techniques. For the railroad site samples, there is a linear correlation between the results obtained using the IPA/UV absorption method and the methylene chloride/GC method. This indicates that one method is a predictor of the other. 


\section{REFERENCES}

- American Society for Testing and Materials, 1996, ASTM Method D-5831-95, Standard Test Method for Screening Fuels in Soils. Annual Book of ASTM Standards, 11.04, 315-320.

American Society for Testing and Materials, 1991, ASTM Practice D-2777-86, Standard Practice for Determination of Precision and Bias of Applicable Methods of Committee D-19 on Water. Annual Book of ASTM Standards, 11.01: 31-44.

American Society for Testing and Materials, 1990a, ASTM Practice E-691-87, Standard Practice for Conducting an Interlaboratory Study to Determine the Precision of a Test Method. Annual Book of ASTM Standards, 14.02: 430-449.

American Society for Testing and Materials, 1990b, ASTM Practice E-177-90, Standard Practice for Use of the Terms Precision and Bias in ASTM Test Methods. Annual Book of ASTM Standards, 14.02: $90-101$.

Guttman, I., S.S. Wilks, and J.S. Hunter, 1971, Introductory Engineering Statistics, J. Wiley and Sons: New York, NY.

MADEP, 1995, Method for the Determination of Extractable Petroleum Hydrocarbons (Public Comment Draft 1.0). Massachusetts Department of Environmental Protection, Woburn, MA.

Schabron, J.F., N.D. Niss, B.K. Hart, and S.S. Sorini, 1995, Remote Chemical Sensor Development: A New Field Screening Method for Soil Fuel Contamination. Laramie, WY, WRI Report WRI95-R016.

- Sorini, S.S. and J.F. Schabron, 1996, Development and Validation of a Standard Test Method for Screening Fuels in Soils. Journal of Testing and Evaluation, JTEVA, In press.

- U.S. EPA, 1986, Method 8015: Nonhalogenated Volatile Organics. Test Methods for Evaluating Solid Waste: Physical/Chemical Methods (SW-846), Vol. 1B, 3rd Ed. 
Table 1. Collaborative Study Data Versus GC-FID Data, mg/Kg

\begin{tabular}{|c|c|c|c|}
\hline $\begin{array}{l}\text { Material } \\
\text { Difference }\end{array}$ & GC-FID Method & $\begin{array}{l}\text { Screening Method } \\
\text { Mean Concentration }\end{array}$ & Percent \\
\hline A & $\begin{array}{c}\bar{x}=122 \\
95 \% \text { C.I. }=103-143^{a}\end{array}$ & $\begin{array}{l}\text { Approximate }=156 \\
\text { Estimated }=179\end{array}$ & $\begin{array}{l}28 \% \\
47 \%\end{array}$ \\
\hline B & $\begin{array}{c}\bar{x}=384 \\
95 \% \text { C.I. }=329-443\end{array}$ & $\begin{array}{l}\text { Approximate }=382 \\
\text { Estimated }=459\end{array}$ & $\begin{array}{l}0.5 \% \\
19 \%\end{array}$ \\
\hline $\mathrm{C}$ & $\begin{array}{c}\bar{x}=841 \\
95 \% \text { C.I. }=719-972\end{array}$ & $\begin{array}{l}\text { Approximate }=802 \\
\text { Estimated }=972\end{array}$ & $\begin{array}{l}5 \% \\
16 \%\end{array}$ \\
\hline $\mathrm{E}$ & $\begin{array}{c}\bar{x}=156 \\
95 \% \text { C.I. }=133-180\end{array}$ & $\begin{array}{l}\text { Approximate }=103 \\
\text { Estimated }=125\end{array}$ & $\begin{array}{l}-34 \% \\
-20 \%\end{array}$ \\
\hline $\mathrm{F}$ & $\begin{array}{c}\bar{x}=826 \\
95 \% \text { C.I. }=704-957\end{array}$ & $\begin{array}{l}\text { Approximate }=618 \\
\text { Estimated }=737\end{array}$ & $\begin{array}{l}-25 \% \\
-11 \%\end{array}$ \\
\hline
\end{tabular}

a. $95 \%$ confidence interval for the concentration of diesel fuel in the test material expanded by $10 \%$ on each side

b. Percent difference between screening method mean approximate concentration and GC-FID $\bar{x}$ value

c. Percent difference between screening method mean estimated concentration and GC-FID $\bar{x}$ value 
Table 2. Blank-Corrected Approximate Concentrations of Diesel Fuel in the Test Materials, $\mathbf{m g} / \mathbf{K g}$

\begin{tabular}{|c|c|c|c|c|c|}
\hline \multirow[b]{2}{*}{ Participant } & \multicolumn{4}{|c|}{ Material } & \multirow[b]{2}{*}{$\mathbf{F}$} \\
\hline & A & B & $\mathrm{C}$ & $\mathrm{E}$ & \\
\hline \multicolumn{6}{|c|}{ Laboratory Data } \\
\hline \multirow[t]{3}{*}{1} & 153 & 364 & 761 & 220 & 714 \\
\hline & 167 & 407 & 881 & 200 & 673 \\
\hline & 178 & 371 & 847 & 220 & 819 \\
\hline \multirow[t]{3}{*}{2} & 172 & 340 & 763 & 101 & 577 \\
\hline & 156 & 366 & 770 & 85 & 598 \\
\hline & 158 & 386 & 762 & 86 & 574 \\
\hline \multirow[t]{3}{*}{3} & 157 & 403 & 830 & 132 & 587 \\
\hline & 159 & 403 & 841 & 120 & 641 \\
\hline & 159 & 405 & 848 & 122 & 634 \\
\hline \multicolumn{6}{|c|}{ Soil Test Kit Data } \\
\hline \multirow[t]{3}{*}{5} & 168 & 389 & 751 & 87 & 593 \\
\hline & 152 & 358 & 768 & 87 & 609 \\
\hline & 156 & 375 & 792 & 101 & 576 \\
\hline \multirow[t]{3}{*}{6} & 137 & 341 & 662 & 95 & 471 \\
\hline & 170 & 378 & 763 & 116 & 597 \\
\hline & 153 & 369 & 768 & 97 & 555 \\
\hline \multirow[t]{3}{*}{8} & 132 & 380 & 793 & 97 & 561 \\
\hline & 107 & 395 & 957 & 98 & 540 \\
\hline & 114 & 375 & 764 & 93 & 607 \\
\hline
\end{tabular}


Table 3. Blank-Corrected Estimated Concentrations of Diesel Fuel in the Test Materials, $\mathbf{m g} / \mathrm{Kg}$

\begin{tabular}{|c|c|c|c|c|c|}
\hline \multicolumn{6}{|c|}{ Material } \\
\hline Participant & $\mathrm{A}$ & B & $\mathrm{C}$ & $\mathrm{E}$ & $F$ \\
\hline \multicolumn{6}{|c|}{ Laboratory Data } \\
\hline \multirow[t]{3}{*}{1} & 182 & 435 & 906 & 262 & 853 \\
\hline & 199 & 460 & 1,048 & 234 & 828 \\
\hline & 212 & 442 & 1,008 & 264 & 1,085 \\
\hline \multirow[t]{3}{*}{2} & 216 & 424 & 949 & 127 & 727 \\
\hline & 195 & 457 & 957 & 106 & 754 \\
\hline & 197 & 481 & 948 & 108 & 724 \\
\hline \multirow[t]{3}{*}{3} & 177 & 455 & 937 & 150 & 663 \\
\hline & 180 & 455 & 949 & 136 & 724 \\
\hline & 179 & 457 & 958 & 138 & 716 \\
\hline \multicolumn{6}{|c|}{ Soil Test Kit Data } \\
\hline \multirow[t]{3}{*}{5} & 204 & 473 & 914 & 107 & 723 \\
\hline & 185 & 436 & 935 & 107 & 742 \\
\hline & 189 & 457 & 965 & 123 & 702 \\
\hline \multirow[t]{3}{*}{6} & 165 & 409 & 794 & 114 & 566 \\
\hline & 204 & 453 & 915 & 139 & 716 \\
\hline & 183 & 443 & 921 & 116 & 666 \\
\hline \multirow[t]{3}{*}{8} & 151 & 528 & 1,115 & 137 & 783 \\
\hline & 117 & 552 & 1,335 & 138 & 750 \\
\hline & 127 & 521 & 1,065 & 131 & 851 \\
\hline
\end{tabular}


Table 4. Final Statistics for the Approximate Concentration of Diesel Fuel in the Sand and Organic Soil Samples, $\mathrm{mg} / \mathrm{Kg}$

\begin{tabular}{cccc}
\hline Material & $\begin{array}{c}\text { Mean Concentration } \\
\bar{x}_{\mathrm{a}}\end{array}$ & $\begin{array}{c}\text { Reproducibility } \\
\text { Standard Deviation } \\
\mathrm{s}_{\mathrm{Ra}}{ }^{2}\end{array}$ & $\begin{array}{c}\text { Repeatability } \\
\text { Standard Deviation } \\
\mathrm{s}_{\mathrm{ra}}{ }^{\mathrm{b}}\end{array}$ \\
\hline A & 162 & 8 & \\
B & 383 & 25 & 9 \\
C & 812 & 50 & 19 \\
E & 108 & 25 & 36 \\
F & 646 & 82 & 8 \\
& & & 47 \\
A & 143 & 24 & 13 \\
B & 373 & 16 & 15 \\
C & 780 & 79 & 5 \\
E & 95 & 5 & 28 \\
F & 579 & 26 & 50 \\
\hline
\end{tabular}

a. Reproducibility (between participants) standard deviation for determining approximate concentration

b. Repeatability (within participant) standard deviation for determining approximate concentration 
Table 5. Final Statistics for the Estimated Concentration of Diesel Fuel in the Sand and Organic Soil Samples, $\mathrm{mg} / \mathrm{Kg}$

\begin{tabular}{|c|c|c|c|}
\hline Material & $\begin{array}{c}\text { Mean Concentration } \\
\bar{x}_{\mathrm{e}}\end{array}$ & $\begin{array}{c}\text { Reproducibility } \\
\text { Standard Deviation } \\
\mathrm{s}_{\mathrm{Re}}{ }^{\mathrm{a}}\end{array}$ & $\begin{array}{c}\text { Repeatability } \\
\text { Standard Deviation } \\
\mathbf{r} \\
\mathbf{r e}\end{array}$ \\
\hline & & Laboratory Data & \\
\hline A & 193 & 15 & 11 \\
\hline B & 452 & 16 & 18 \\
\hline $\mathrm{C}$ & 962 & 41 & 43 \\
\hline $\mathrm{E}$ & 127 & 21 & 10 \\
\hline \multirow[t]{2}{*}{$\mathrm{F}$} & 759 & 75 & 24 \\
\hline & & Soil Test Kit Data & \\
\hline A & 170 & 35 & 16 \\
\hline B & 475 & 54 & 19 \\
\hline $\mathrm{C}$ & 968 & 117 & 48 \\
\hline $\mathrm{E}$ & 123 & 14 & 10 \\
\hline $\mathrm{F}$ & 722 & 85 & 54 \\
\hline
\end{tabular}

a. Reproducibility (between participants) standard deviation for determining estimated concentration

b. Repeatability (within participant) standard deviation for determining estimated concentration 
Table 6. Portable Field Equipment and Laboratory Equipment Mean Concentration Values

Approximate Diesel Concentration Determinations, $\mathrm{mg} / \mathrm{Kg}$

\begin{tabular}{|c|c|c|c|}
\hline Material $^{\mathrm{a}}$ & $\underline{\text { Soil Test Kit Mean Value }}$ & Laboratory Mean Value & $\not$ Difference \\
\hline A & 143 & 162 & $-12 \%$ \\
\hline B & 373 & 383 & $-3 \%$ \\
\hline $\mathrm{C}$ & 780 & 812 & $-4 \%$ \\
\hline $\mathrm{E}$ & 95 & 108 & $-12 \%$ \\
\hline $\mathrm{F}$ & 579 & 646 & $-10 \%$ \\
\hline
\end{tabular}

Estimated Diesel Concentration Determinations, $\mathrm{mg} / \mathrm{Kg}$

\begin{tabular}{cccc} 
Material $^{\text {a }}$ & Soil Test Kit Mean Value & & Laboratory Mean Value \\
A & 170 & 193 & \% Difference \\
B & 475 & 452 & $-12 \%$ \\
C & 968 & 962 & $5 \%$ \\
E & 123 & 127 & $1 \%$ \\
F & 722 & 759 & $-3 \%$ \\
\hline
\end{tabular}

a. Materials A, B, and C are a diesel-spiked sand, and materials $\mathrm{E}$ and $\mathrm{F}$ are a dieselspiked organic soil. 
Table 7. Reproducibility Using Laboratory Equipment ${ }^{a}$

Approximate Concentration Statistics for Testing the Sand

$\begin{array}{lrcc}\underline{\underline{x}} & \underline{\underline{s}}_{\mathrm{Ra}}^{\mathrm{b}} & \underline{2.8 \mathrm{~s}_{\mathrm{Ra}}} & \underline{2.8 \mathrm{CV} \%_{\mathrm{Ra}}} \\ 162 & 8 & 22 & 14 \% \\ 383 & 25 & 70 & 18 \% \\ 812 & 50 & 140 & 17 \%\end{array}$

Estimated Concentration Statistics for Testing the Sand

$\begin{array}{lccc}\underline{\bar{x}} & \underline{\underline{s}}_{\mathrm{Re}-}^{c} & \underline{2.8 \mathrm{~s}_{\mathrm{Re}}} & \underline{2.8 \mathrm{CV} \%}{ }_{\mathrm{Re}} \\ 193 & 15 & 42 & 22 \% \\ 452 & 16 & 45 & 10 \% \\ 962 & 41 & 115 & 12 \%\end{array}$

Approximate Concentration Statistics for Testing the Organic Soil

$\begin{array}{lccc}\overline{\underline{x}} & \underline{\mathrm{s}}_{\mathrm{Ra}} & \underline{2.8 \mathrm{~s}_{\mathrm{Ra}}} & \underline{2.8 \mathrm{CV} \%}{ }_{\mathrm{Ra}} \\ 108 & 25 & 70 & 65 \% \\ 646 & 82 & 230 & 35 \%\end{array}$

Estimated Concentration Statistics for Testing the Organic Soil

$\begin{array}{lccc}\bar{x} & \underline{S}_{\mathrm{Re}} & 2.8 \mathrm{~S}_{\mathrm{Re}} & \underline{2.8 \mathrm{CV} \%_{\mathrm{Re}}} \\ 127 & 21 & 59 & 46 \% \\ 759 & 75 & 210 & 28 \%\end{array}$

a. Units are $\mathrm{mg} / \mathrm{Kg}$ unless otherwise specified.

b. Reproducibility (between participants) standard deviation for determining approximate concentration

c. Reproducibility (between participants) standard deviation for determining estimated concentration 
Table 8. Reproducibility Using the Field Soil Test Kit ${ }^{\mathrm{a}}$

Approximate Concentration Statistics for Testing the Sand

$\begin{array}{lccc}\overline{\underline{x}} & \underline{\mathrm{s}}_{\mathrm{Ra}}^{\mathrm{b}} & \underline{2.8 \mathrm{~s}_{\mathrm{Ra}}} & \underline{2.8 \mathrm{CV} \%}{ }_{\mathrm{Ra}} \\ 143 & 24 & 67 & 47 \% \\ 373 & 16 & 45 & 12 \% \\ 780 & 79 & 221 & 28 \%\end{array}$

Estimated Concentration Statistics for Testing the Sand

$\begin{array}{cccc}\underline{\bar{x}} & \underline{\mathrm{s}}_{\mathrm{Re}-\mathrm{c}}{ }^{\mathrm{c}} & \underline{2.8 \mathrm{~s}_{\mathrm{Re}}} & \underline{\underline{2.8 \mathrm{CV}}}_{\mathrm{Re}} \\ 170 & 35 & 98 & 58 \% \\ 475 & 54 & 151 & 32 \% \\ 968 & 117 & 328 & 34 \%\end{array}$

Approximate Concentration Statistics for Testing the Organic Soil

$\begin{array}{rrcc}\overline{\underline{x}} & \underline{\mathrm{s}}_{\mathrm{Ra}} & \underline{2.8 \mathrm{~s}_{\mathrm{Ra}}} & \underline{2.8 \mathrm{CV} \%_{\mathrm{Ra}}} \\ 95 & 5 & 14 & 15 \% \\ 579 & 26 & 73 & 13 \%\end{array}$

Estimated Concentration Statistics for Testing the Organic Soil

$\begin{array}{lccc}\underline{\bar{x}} & \underline{\mathrm{s}}_{\mathrm{Re}} & \underline{2.8 \mathrm{~s}_{\mathrm{Re}}} & \underline{2.8 \mathrm{CV} \%}{ }_{\mathrm{Re}} \\ 123 & 14 & 39 & 32 \% \\ 722 & 85 & 238 & 33 \%\end{array}$

a. Units are $\mathrm{mg} / \mathrm{Kg}$ unless otherwise specified.

b. Reproducibility (between participants) standard deviation for determining approximate concentration

c. Reproducibility (between participants) standard deviation for determining estimated concentration 
Table 9. Repeatability Using Laboratory Equipment ${ }^{\mathrm{a}}$

Approximate Concentration Statistics for Testing the Sand

\begin{tabular}{|c|c|c|c|}
\hline$\underline{\bar{x}}$ & $\underline{\mathbf{S}}_{\mathrm{ra}}^{\mathrm{b}}$ & $2.8 \mathrm{~s}_{\mathrm{ra}}$ & $2.8 \mathrm{CV} \%$ \\
\hline 162 & 9 & 25 & $16 \%$ \\
\hline 383 & 19 & 53 & $14 \%$ \\
\hline 812 & 36 & 101 & $12 \%$ \\
\hline
\end{tabular}

Estimated Concentration Statistics for Testing the Sand

$\begin{array}{cccc}\underline{\bar{x}} & \underline{\mathrm{s}}_{\mathrm{re}-}^{\mathrm{c}} & \underline{2.8 \mathrm{~s}_{\mathrm{re}}} & \underline{2.8 \mathrm{CV} \%}{ }_{\mathrm{re}} \\ 193 & 11 & 31 & 16 \% \\ 452 & 18 & 50 & 11 \% \\ 962 & 43 & 120 & 12 \%\end{array}$

Approximate Concentration Statistics for Testing the Organic Soil

$\begin{array}{lrcc}\underline{\bar{x}} & \underline{\mathrm{s}}_{\mathrm{ra}} & \underline{2.8 \mathrm{~s}_{\mathrm{ra}}} & \underline{2.8 \mathrm{CV} \%_{\mathrm{ra}}} \\ 108 & 8 & 22 & 21 \% \\ 646 & 47 & 132 & 20 \%\end{array}$

Estimated Concentration Statistics for Testing the Organic Soil

$\begin{array}{cccc}\underline{\bar{x}} & \underline{\mathrm{s}}_{\mathrm{re}} & {\underline{2.8 \mathrm{~s}_{\mathrm{re}}}} \underline{\underline{2.8 \mathrm{CV}}}_{\mathrm{re}} \\ 127 & 10 & 28 & 22 \% \\ 759 & 24 & 67 & 9 \%\end{array}$

a. Units are $\mathrm{mg} / \mathrm{Kg}$ unless otherwise specified.

b. Repeatability (within participant) standard deviation for determining approximate concentration

c. Repeatability (within participant) standard deviation for determining estimated concentration 
Table 10. Repeatability Using the Field Soil Test Kit ${ }^{\mathrm{a}}$

Approximate Concentration Statistics for Testing the Sand

$\begin{array}{lccc}\overline{\underline{x}} & \underline{\underline{\mathrm{s}}}_{\mathrm{ra}}^{\mathrm{b}} & \underline{2.8 \mathrm{~s}_{\mathrm{ra}}} & \underline{2.8 \mathrm{CV} \%}_{\mathrm{ra}} \\ 143 & 13 & 36 & 25 \% \\ 373 & 15 & 42 & 11 \% \\ 780 & 70 & 196 & 25 \%\end{array}$

Estimated Concentration Statistics for Testing the Sand

$\begin{array}{lccc}\overline{\mathbf{x}} & \underline{\mathrm{s}}_{\mathrm{re}}^{\mathrm{c}} & \underline{2.8 \mathrm{~s}_{\mathrm{re}}} & \underline{\underline{2.8 C V}}_{\mathrm{re}} \\ 170 & 16 & 45 & 26 \% \\ 475 & 19 & 53 & 11 \% \\ 968 & 48 & 134 & 14 \%\end{array}$

Approximate Concentration Statistics for Testing the Organic Soil

$\begin{array}{rrcc}\overline{\bar{x}} & \underline{\mathrm{s}}_{\mathrm{ra}} & 2.8 \mathrm{~s}_{\mathrm{ra}} & 2.8 \mathrm{CV} \%_{\mathrm{ra}} \\ 95 & 5 & 14 & 15 \% \\ 579 & 28 & 78 & 13 \%\end{array}$

Estimated Concentration Statistics for Testing the Organic Soil

$\begin{array}{lccc}\underline{\bar{x}} & \underline{\mathrm{s}}_{\mathrm{re}} & {\underline{2.8 \mathrm{~s}_{\mathrm{re}}}} & \underline{\mathbf{2 . 8 C V}}_{\mathrm{re}} \\ 123 & 10 & 28 & 23 \% \\ 722 & 54 & 151 & 21 \%\end{array}$

a. Units are $\mathrm{mg} / \mathrm{Kg}$ unless otherwise specified.

b. Repeatability (within participant) standard deviation for determining approximate concentration

c. Repeatability (within participant) standard deviation for determining estimated concentration 
Table 11. 95\% Reproducibility Limits ${ }^{a}$ for Testing Diesel-Spiked Sand and Organic Soil

Material: Diesel-Spiked Sand

Equipment: Laboratory

Test Range, $\mathrm{mg} / \mathrm{Kg}$

162-962 (approximate or estimated)
95\% Reproducibility Limit (\% of the test result) $15 \%$ (10 to $22 \%)$

\section{Material: Diesel-Spiked Sand}

Equipment: Soil Test Kit

Test Range, $\mathrm{mg} / \mathrm{Kg}$

143 (approximate)

170 (estimated)

373 (approximate)

780 (approximate)

475-968 (estimated)
95\% Reproducibility Limit (\% of the test result)

$$
\begin{aligned}
& 47 \% \\
& 58 \% \\
& 12 \% \\
& 28 \% \\
& 33 \%(32 \%, 34 \%)
\end{aligned}
$$

Material: Diesel-Spiked Organic Soil

Equipment: Laboratory

Test Range, $\mathrm{mg} / \mathrm{Kg}$

108 (approximate)

127 (estimated)

646 (approximate)

759 (estimated)
95\% Reproducibility Limit (\% of the test result)

$65 \%$

$46 \%$

$35 \%$

$28 \%$

Material: Diesel-Spiked Organic Soil

Equipment: Soil Test Kit

Test Range. $\mathrm{mg} / \mathrm{Kg}$

95-579 (approximate)

123-722 (estimated)
95\% Reproducibility Limit (\% of the test result)

$$
\begin{aligned}
& 14 \%(15 \%, 13 \%) \\
& 33 \%(32 \%, 33 \%)
\end{aligned}
$$

a. Between participants 
Table 12. 95\% Repeatability Limits ${ }^{\mathrm{a}}$ for Testing Diesel-Spiked Sand and Organic Soil Using Laboratory Equipment

\section{Material: Diesel-Spiked Sand}

Test Range. $\mathrm{mg} / \mathrm{Kg}$

25\% Repeatability Limit (\% of the test result)

162-962 (approximate or estimated)

$13 \%(11$ to $16 \%)$

Material: Diesel-Spiked Organic Soil

Test Range, $\mathrm{mg} / \mathrm{Kg}$

108-646 (approximate)

127 (estimated)

759 (estimated)
95\% Repeatability Limit (\% of the test result)

$21 \%(21 \%, 20 \%)$

$22 \%$

$9 \%$

Materials: Diesel-Spiked Sand and Diesel-Spiked Organic Soil

Test Range, $\mathrm{mg} / \mathrm{Kg}$

108-962 (approximate or estimated)
Overall 95\% Repeatability Limit

(\% of the test result)

$15 \%$ ( 9 to $22 \%$ )

a. Within participant 
Table 13. 95\% Repeatability Limits for Testing Diesel-Spiked Sand and Organic Soil Using the Field Soil Test Kit

Material: Diesel-Spiked Sand

Test Range, $\mathrm{mg} / \mathrm{Kg}$

95\% Repeatability Limit (\% of the test result)

143-170 (approximate or estimated)

$26 \%(25 \%, 26 \%)$

373-475 (approximate or estimated)

780 (approximate)

$11 \%(11 \%, 11 \%)$

968 (estimated)

$25 \%$

$14 \%$

Material: Diesel-Spiked Organic Soil

Test Range. $\mathrm{mg} / \mathrm{Kg}$

95-579 (approximate)

123-722 (estimated)
95\% Repeatability Limit (\% of the test result)

$14 \%(15 \%, 13 \%)$

$22 \%(23 \%, 21 \%)$

Materials: Diesel-Spiked Sand and Diesel-Spiked Organic Soil

Test Range. $\mathrm{mg} / \mathrm{Kg}$

95-968 (approximate or estimated)
Overall $95 \%$ Repeatability Limit (\% of the test result)

$18 \%$ (11 to $26 \%)$

a. Within participant 
Table 14. ASTM D-5831-95 and MADP Analysis Results for Five DieselContaminated Soils from a Railroad Site, $\mathrm{mg} / \mathrm{kg}$ Dry Soil Basis

\begin{tabular}{lcrrr}
\hline & & \multicolumn{3}{c}{ MADP EPH Method } \\
Sample & ASTM D-5831-95 & Aliphatics & $\underline{\text { Aromatics }}$ & Total EPH \\
G16C1 & 23,000 & 5,300 & 2,000 & 7,300 \\
G16D1 & 7,600 & 870 & 470 & 1,340 \\
G17D1 & 68,000 & 44,000 & 12,000 & 56,000 \\
G19E1 & 13,000 & 3,400 & 1,300 & 4,700 \\
G23C1 & 16,000 & 3,100 & 1,100 & 4,200 \\
& & & & \\
\hline
\end{tabular}


Table 15. Percent Recovery from Soils Spiked to $422 \mathrm{mg} / \mathrm{kg}$ Diesel Fuel

\begin{tabular}{|c|c|c|c|c|}
\hline Extraction Solvent: & IPA & & Freon & \\
\hline Measurement: & $\underline{\text { UV }}$ & $\underline{\text { UV }}$ & $\underline{\mathrm{IR}}$ & GC \\
\hline \multicolumn{5}{|l|}{ Sand } \\
\hline No Aging & 112 & 92 & 102 & 89 \\
\hline $40^{\circ} \mathrm{C}, 2$ Weeks & 117 & 80 & 66 & 68 \\
\hline $60^{\circ} \mathrm{C}, 2$ Weeks & 52 & 10 & 9 & 9 \\
\hline \multicolumn{5}{|l|}{$\underline{\text { Silt }}$} \\
\hline No Aging & 105 & 97 & 101 & 72 \\
\hline $40^{\circ} \mathrm{C}, 2$ Weeks & 77 & 61 & 59 & 70 \\
\hline $60^{\circ} \mathrm{C}, 2$ Weeks & 105 & $<2$ & 6 & 2 \\
\hline \multicolumn{5}{|l|}{ Clay } \\
\hline No Aging & 100 & 85 & 65 & 56 \\
\hline $40^{\circ} \mathrm{C}, 2$ Weeks & 110 & 79 & 92 & 87 \\
\hline $60^{\circ} \mathrm{C}, 2$ Weeks & 78 & $<2$ & 6 & 2 \\
\hline \multicolumn{5}{|l|}{ Potting Soil } \\
\hline No Aging & 100 & 70 & 66 & 36 \\
\hline $40^{\circ} \mathrm{C}, 2$ Weeks & 86 & 26 & 62 & 33 \\
\hline $60^{\circ} \mathrm{C}, 2$ Weeks & 57 & $<2$ & 18 & $<1$ \\
\hline
\end{tabular}

